\title{
Diclofenac-induced biochemical changes in nephrotoxicity among male Albino rats
}

\author{
Sivaraj R. ${ }^{*}$, Umarani $S^{2}{ }^{2}$
}

${ }^{1}$ Department of Pharmacology, Aarupadaiveedu Medical College and Hospital, Kirumampakkam, Puducherry, India

${ }^{2}$ Department of Anatomy, Rajah Muthiah Medical College and Hospital, Annamalai University, Annamalainagar, Tamil Nadu, India

Received: 11 January 2018 Accepted: 27 February 2018

*Correspondence to:

Dr. Sivaraj R.,

Email: drrsivaraj@gmail.com

Copyright: (c) the author(s), publisher and licensee Medip Academy. This is an openaccess article distributed under the terms of the Creative Commons Attribution NonCommercial License, which permits unrestricted noncommercial use, distribution, and reproduction in any medium, provided the original work is properly cited.

\begin{abstract}
Background: Nonsteroidal anti-inflammatory drugs (NSAIDs) are associated with adverse renal effects caused by the reduction in synthesis of renal prostaglandins in sensitive persons or animal species, and potentially during longterm use in non-sensitive persons if resistance to side effects decreases with age. The effects of diclofenac sodium on the kidneys were studied during 4 1/2 hours in eight patients with normal renal function. Urinary output decreased within 10 min after the injection, and maximally by $80 \%$. The renal plasma flow and the glomerular filtration rate initially diminished significantly, by $35 \%$, but began to increase after only 2 hours. The dominant and persistent effect was a reduction of free water clearance, with maximum fall from 5.9 to $0.08 \mathrm{ml} / \mathrm{min}$ after $21 / 2$ hours. Aim: The aim of this study was to evaluate the effects of diclofenac-induced acute nephrotoxicity using biochemical parameters in rats.

Methods: 12 male Wistar rats allotted in 4 equal groups were intraperitoneally injected with $0,10,50$ and $100 \mathrm{mg} / \mathrm{kg}$ diclofenac, respectively and 12 hours after injection, blood serum samples were collected for assessment of basic renal function test parameters such as urea, creatinine, and uric acid, sodium, Potassium.

Results: Rats treated up to $50 \mathrm{mg} / \mathrm{kg}$ diclofenac were considered to be within normal range in rats. By increase in dose more than $50 \mathrm{mg} / \mathrm{kg}$ showed significant increases in uremia were evidenced in intoxicated animals. Observed specifically in group IV Rats.

Conclusions: In this study, uremia, as an indicator of kidney damage, was significantly increased depending on dose. Diclofenac may cause kidney damage depending on dose and this effect may also be observed. NSAIDs-induced nephrotoxicity may be due to the inhibitory effect of these drugs on prostaglandin synthesis, thus causing kidney ischemia.
\end{abstract}

Keywords: Diclofenac, Impaired renal function, Nephrotoxicity, Uremia

\section{INTRODUCTION}

Nonsteroidal anti-inflammatory drugs (NSAIDs) represent one of the most common classes of medications used worldwide, with an estimated usage of $>30$ million per day. ${ }^{1}$ NSAIDs exert anti-inflammatory, analgesic and antipyretic effects through the suppression of prostaglandin (PG) synthesis, by inhibiting the enzyme cyclooxygenase $(\mathrm{COX})$. The gastrointestinal tract and the kidneys are important targets for untoward clinical events associated with the use of NSAIDs. ${ }^{2}$ Approximately 2.5 million Americans experience NSAID-mediated renal effects yearly. Nonselective NSAIDs inhibit both COX-1 (expressed constitutively in the kidney) and COX-2 (inducible in most tissues in response to injury or inflammation, but also present at detectable levels in normal adult mammalian kidneys), the rate-limiting enzymes for the production of PGs and thromboxane (TX) $\mathrm{COX}-2$ is regulated in response to intravascular volume 
COX-1 functions mainly in the control of renal hemodynamic and glomerular filtration rate (GFR), while COX-2 functions primarily affect salt and water excretion. ${ }^{3}$ Blockade of either or both of these enzymes can have, therefore, different effects on renal function. PGs regulate a wide variety of renal functions. PGE2 is considered to be mainly a tubular PG and PGI2 a vascular PG. However, renal arterioles, tubules, medullary interstitial cells, and mesangial cells are able to produce both PGE2 and PGI2. PGE2 regulates sodium and chloride transport in the loop of Henle and modulates water transport and renal medullary blood flow. ${ }^{4}$ The physiological effects of PG2 are mediated through the four G-protein-coupled transmembrane prostaglandin receptors EP1, EP2, EP3, and EP4. PGI2 regulates renal vascular tone, GFR and renin release COX-2 activates the reninangiotensin system, while an increased activity of the renin-angiotensin system inhibits COX-2. PGI2 and PGE2 increase potassium secretion primarily by stimulating the secretion of renin and activating the renin-angiotensinaldosterone system. ${ }^{5}$ Macula densa sensing of tubule $\mathrm{NaCl}$ concentration at the distal end of the loop of Henle serves as a primary regulatory step in renin secretion and tubuloglomerular feedback. Sodium retention is a welldescribed feature of all nonselective NSAIDs due to inhibition of COX-2 by these drugs. ${ }^{6}$ Therefore, it is predictable that $\mathrm{COX}-2$ selective inhibitors may have similar effects. Some serum parameters are used to evaluate organ damage. Increased serum urea and creatinine concentrations are accepted as indicators of kidney damage. It has been shown that diclofenac may cause nephrotoxicity in rodents and increased serum urea and creatinine concentrations are accepted as markers of infection- and chemical agent-induced nephrotoxicity in rats. ${ }^{7}$

\section{METHODS}

This prospective interventional study was conducted for a period of 3 months from August to November 2015 in the department of pharmacology which is attached to wellconstructed animal house section in Rajah Muthiah Medical College and Hospital. Institutional animal ethical committee approval was given by the committee members on July 2015.Totally 12 male Wister rats of weight around 150-250 grams were divided into 4 equal groups. The animals were housed under standard conditions of temperature, relative humidity $(55 \pm 5 \%$ ), and light (12 h light/dark cycles) were used. They were fed with standard pellet diet and water ad libitum.

- Group - I receive $(0 \mathrm{mg})$ of diclofenac.

- Group - II (10mg) of diclofenac.

- Group - III (50mg) of diclofenac.

- $\quad$ Group IV (100mg) of diclofenac.

Diclofenac was injected by intraperitoneally after 12 hours after injection, blood serum samples were collected for assessment of basic renal function test parameters such as urea, creatinine, and uric acid, sodium, Potassium. Biochemical analysis of renal parameters was analyzed by automated analyzer [ATICO Med Lab Analyser1781].

\section{Statistical analysis}

The tests of significance of the results of basic renal parameters were calculated using one-way ANOVA test followed by students paired' test. P value less than 0.05 was considered significant (SPSS 18.0).

\section{RESULTS}

Totally 12 male Wister rats of weight around 150-250 grams were divided into 4 equal groups. The animals were housed under standard conditions of temperature, relative humidity $(55 \pm 5 \%)$, and light (12 h light/dark cycles) were used. They were fed with standard pellet diet and water $a d$ libitum.

Diclofenac was injected by intraperitoneally after 12 hours after injection, blood serum samples were collected for assessment of basic renal function test parameters such as urea, creatinine, and uric acid, sodium, Potassium. In a group, I, II, II serum urea, serum creatinine, serum uric acid, sodium, and potassium level is found to be in within normal range which doesn't show gross variations of $\mathrm{p}$ value $<0.005$ which is not statically significant. In group IV serum urea level is found to be high than the normal range when compared to other groups of p-value $<0.001$ which is found to be statically significant.

Table: 1 The renal profile parameters among 4 groups of male Albino wistar rats after the specified dosage of diclofenac administration $(n=12)$.

\begin{tabular}{|c|c|c|c|c|}
\hline Renal profile parameters & $\begin{array}{l}\text { Group-I (N=3) } \\
\text { Omg }\end{array}$ & $\begin{array}{l}\text { Group-II } \\
(\mathrm{N}=3) 10 \mathrm{mg}\end{array}$ & $\begin{array}{l}\text { Group-III } \\
(\mathrm{N}=3) 50 \mathrm{mg}\end{array}$ & $\begin{array}{l}\text { Group-IV } \\
\text { (N=3) 100mg }\end{array}$ \\
\hline Urea (mg/dl) & $18.11 \pm 0.82$ & $23.21 \pm 1.98$ & $29.45 \pm 3.44$ & $45.98 \pm 2.31$ \\
\hline Uric acid $(\mathrm{mg} / \mathrm{dl})$ & $8.76 \pm 8.9$ & $14.54 \pm 5.6$ & $19.12 \pm 9.0$ & $22.90 \pm 0.7$ \\
\hline Serum creatinine (mg/dl) & $4.67 \pm 4.5$ & $17.30 \pm 0.66$ & $23.09 \pm 0.67$ & $41.66 \pm 0.56$ \\
\hline Sodium $(\mathrm{mEq} / \mathrm{L})$ & $151.07 \pm 0.83$ & $160.01 \pm 0.77$ & $165 \pm 8.9$ & $170.88 \pm 4.5$ \\
\hline Potassium (mEq/L) & $6.0 \pm 0.5$ & $8.08 \pm 0.3$ & $9.03 \pm 0.5$ & $11.08 \pm 7.8$ \\
\hline
\end{tabular}




\section{DISCUSSION}

Diclofenac, a non-steroidal anti-inflammatory drug, have an adverse effect on renal physiology. Inhibit renal prostaglandin production, limiting renal afferent vasodilation, increases afferent resistance; this causes the glomerular capillary pressure to drop below normal values and the GFR to decrease. ${ }^{8}$ This manifests as acute renal dysfunction, fluid, and electrolyte disorders and pathologically reveal renal papillary necrosis, interstitial nephritis. ${ }^{9}$ Serum analysis of urea, creatinine, uric acid, sodium, potassium was impaired and severe tubular damage was observed in the study. DCL sodium-induced nephrotoxicity was manifested by elevation in the serum levels of creatinine, urea, and uric acid, and was confirmed through oxidative stress disturbances that were previously reported by many authors. ${ }^{10}$ Creatinine is an anhydride of creatine and is formed by spontaneous and irreversible reaction during skeletal muscle metabolism. Serum creatinine is one of the kidney related variables that indicate renal toxicity. Creatinine may be indicative of kidney-specific physiological disorders. ${ }^{11}$ An increase in serum creatinine is a biomarker for renal damage. Urea is formed by the liver and considered the main end product of protein catabolism in carnivorous and omnivorous species. Plasma urea levels can be a reliable indication of renal function as a significant. ${ }^{12}$ Uric acid is produced by the breakdown of purines and by straight synthesis from 5phosphoribosyl pyrophosphate (5-PRPP) and glutamine. Uric acid is passed in the urine in humans, but in other mammals, uric acid is further oxidized to allantoin before excretion. Another explanation of the elevated serum uric acid level in DCL group is the defence mechanisms against free radical-created oxidative damage causes an increase in the concentration of uric acid (electron donors) in order to reduce free radicals. ${ }^{13}$ This effect may aggravate the condition of renal damage resulted from uric acid. Chemokines such as monocyte chemoattractant protein-1 (MCP-1) are expressed in glomeruli of animals and humans with glomerulonephritis. MCP-1 is involved in the monocyte/macrophage infiltration into glomeruli and the renal interstitium. ${ }^{14}$ Mesangial cell production and release of MCP-1 is stimulated by cytokines and growth factors while dexamethasone or PGE reduces the glomerular MCP-1 expression, suggesting that endogenously formed PGs can modulate the formation of MCP-1 and influence the clinical outcome of experimental glomerulonephritis. In very rare cases, NSAIDs may induce glomerular disease, such as membranous nephropathy which is clinically complicated by nephrotic syndrome. ${ }^{15}$ Not only renal transplant patients but also patients with different forms of glomerulonephritis (e.g., membranous nephropathy, focal segmental glomerulosclerosis, steroidresistant minimal change nephropathy) may be treated with a calcineurin inhibitor. ${ }^{16}$ The kidney is vulnerable toward adverse effects of the calcineurin inhibitors cyclosporine A and tacrolimus, including a decrease of GFR, tubular dysfunction, glomerulosclerosis, and renal interstitial fibrosis. ${ }^{17}$ When possible, selective and nonselective NSAIDs should be avoided in patients with
CKD, congestive heart failure, or liver cirrhosis to prevent ARF. There is some evidence to support an increased incidence of adverse effects with increased dosing of selective and nonselective NSAIDs Some medications, such as ACE inhibitors, angiotensin II-receptor blockers, and $\beta$-blockers may increase NSAID-related renal complications..$^{18}$ Hypernatremia may complicate the use of the osmotic cathartics lactulose and sorbitol that are commonly used in the treatment of hepatic encephalopathy or drug intoxications, respectively. ${ }^{19}$ In these settings, water is lost in excess of sodium plus potassium resulting in a reduction of TBW without a commensurate reduction in $\mathrm{Na}_{\mathrm{e}}{ }^{+}$and $\mathrm{K}_{\mathrm{e}}^{+}$, thus leading to increased plasma sodium according to the Edelman equation. Taking into consideration that the mental status is often impaired in the course of hepatic encephalopathy or drug overdose, these stool water losses not infrequently remain unreplaced resulting in an increase in the serum sodium concentration. ${ }^{20}$

\section{CONCLUSION}

It is concluded that depending on the dose of diclofenac administered which increased urea concentrations, an indicator of kidney damage in serum, kidney damage cannot be evaluated using the stereological method or by serum oxidative stress parameters despite slight variations of them mainly observed with $50 \mathrm{mg} / \mathrm{kg}$ diclofenac. More severe damage in organs is necessary in order to evaluate damage using the above-mentioned biochemical parameters.

\section{Funding: No funding sources}

Conflict of interest: None declared

Ethical approval: The study was approved by the Institutional Ethics Committee

\section{REFERENCES}

1. Arroyo V, Planas R, Gaya J, Deulofeu R, Rimola A, Pérez-Ayuso Om, et al. Sympathetic nervous activity, renin-angiotensin system and renal excretion of prostaglandin E2 in cirrhosis. Relationship to functional renal failure and sodium and water excretion. European journal of clinical investigation. 1983 Jun 1;13(3):271-8.

2. Bosch-Marcé M, Clària J, Titos E, Masferrer JL, Altuna R, Poo JL, et al. Selective inhibition of cyclooxygenase 2 spares renal function and prostaglandin synthesis in cirrhotic rats with ascites. Gastroenterology. 1999 May 1;116(5):1167-75.

3. Boyer TD, Zia P. Reynolds, T.B. Effect of indomethacin and prostaglandin $\mathrm{A} 1$ on renal function and plasma renin activity in alcoholic liver disease. Gastroenterology. 1979;77:215-22.

4. Brater DC. Effects of nonsteroidal anti-inflammatory drugs on renal function: focus on cyclooxygenase-2selective inhibition. The American Journal of Medicine. 1999 Dec 13;107(6):65-70. 
5. Campbell MS, Makar GA. Safety of short-term administration of celecoxib in decompensated cirrhosis. Hepatology. 2005 Jul 1;42(1):237.

6. Cheng HF, Wang JL, Zhang MZ, Miyazaki Y, Ichikawa I, McKanna JA, et al. Angiotensin II attenuates renal cortical cyclooxygenase-2 expression. The Journal of clinical investigation. $1999 \mathrm{Apr}$ 1;103(7):953-61.

7. Clària, J. Safety of short-term administration of celecoxib in decompensated cirrhosis. Hepatology 2005;42:238.

8. Ginès P, Schrier RW. Renal failure in cirrhosis. New England Journal of Medicine. 2009 Sep 24;361(13):1279-90.

9. Guevara M, Abecasis R, Terg R. Effect of celecoxib on renal function in cirrhotic patients with ascites. A pilot study. Scandinavian J of Gastroenterology. 2004 Jan 1;39(4):385-6.

10. Harding P, Sigmon DH, Alfie ME, Huang PL, Fishman MC, Beierwaltes $\mathrm{WH}$, et al Cyclooxygenase-2 mediates increased renal renin content induced by low-sodium diet. Hypertension. 1997 Jan 1;29(1):297-302.

11. Ichihara A, Imig JD, Inscho EW, Navar LG. Cyclooxygenase-2 participates in tubular flowdependent afferent arteriolar tone: interaction with neuronal NOS. American Journal of Physiology-Renal Physiology. 1998 Oct 1;275(4):F605-12.

12. Kammerl MC, Nüsing RM, Schweda F, Endemann D, Stubanus M, Kees F, et al. Low sodium and furosemide-induced stimulation of the renin system in man is mediated by cyclooxygenase 2. Clinical Pharmacology \& Therapeutics. 2001 Nov 1;70(5):468-74.

13. Komhoff MA, Grone HJ, Klein TH, Seyberth HW, Nusing RM. Localization of cyclooxygenase-1 and-2 in adult and fetal human kidney: implication for renal function. American Journal of Physiology-Renal Physiology. 1997 Apr 1;272(4):F460-8.
14. Bosch-Marcé M, Clària J, Titos E, Masferrer JL, Altuna R, Poo JL, et al. Selective inhibition of cyclooxygenase 2 spares renal function and prostaglandin synthesis in cirrhotic rats with ascites. Gastroenterology. 1999 May 1;116(5):1167-75.

15. LeLorier J, Bombardier C, Burgess E, Moist L, Wright $\mathrm{N}$, Cartier P, et al. Practical considerations for the use of nonsteroidal anti-inflammatory drugs and cyclooxygenase- 2 inhibitors in hypertension and kidney disease. The Canadian Journal of Cardiology. 2002 Dec;18(12):1301-8.

16. López-Parra M, Clària J, Planagumà $\mathrm{A}$, Titos E, Masferrer JL, Woerner BM, et al. Cyclooxygenase-1 derived prostaglandins are involved in the maintenance of renal function in rats with cirrhosis and ascites. British journal of pharmacology. $2002 \mathrm{Feb}$ 1;135(4):891-900.

17. Noroian G, Clive D. Cyclo-oxygenase-2 inhibitors and the kidney. Drug safety. 2002 Mar 1;25(3):165-72.

18. Ros J, Claria J, Jimenez W, Bosch-Marcé M, Angeli $\mathrm{P}$, Arroyo $\mathrm{V}$, et al. Role of nitric oxide and prostacyclin in the control of renal perfusion in experimental cirrhosis. Hepatology. 1995 Sep 1;22(3):915-20.

19. Schricker KA, Hamann MA, Kurtz AR. Nitric oxide and prostaglandins are involved in the macula densa control of the renin system. American Journal of Physiology-Renal Physiology. 1995 Dec 1;269(6):F825-30.

20. Turull À, Piera C, Queralt J. Acute effects of the antiinflammatory cyclooxygenase- 2 selective inhibitor, flosulide, on renal plasma flow and glomerular filtration rate in rats. Inflammation. $2001 \mathrm{Apr}$ 1;25(2):119-28.

Cite this article as: Sivaraj R, Umarani S. Diclofenac-induced biochemical changes in nephrotoxicity among male Albino rats. Int J Basic Clin Pharmacol 2018;7:640-3. 